\title{
Winter temperatures in the second half of the sixteenth century in the central area of the Iberian Peninsula
}

\author{
T. Bullón \\ Departamento de Geografía, Universidad Autónoma de Madrid, Spain \\ Received: 20 May 2008 - Published in Clim. Past Discuss.: 9 June 2008 \\ Revised: 4 December 2008 - Accepted: 4 December 2008 - Published: 15 December 2008
}

\begin{abstract}
This paper studies the winter temperatures of the second part of the sixteenth century in the central area of the Iberian Peninsula. A large number of historical documents that are stored in many different Spanish archives were consulted in order to carry out this research. The data was first arranged and weighted according to the intensity and significance of the meteorological phenomena described and, subsequently, these values were assigned an ordinal index ranging from +4 to -4 . The statistical treatment applied is based on the reconstruction of temperatures equivalent to this ordinal index, expressed as anomalies of the 1961-1990 period, belonging to a reference station located at the approximate geographical center of the area under study. The results show winter thermal conditions different from current ones that, for the most part, stay below the reference average and that occurred with a wide range of variability. The influence that thermal conditions had on the evolution of some environmental aspects are considered based on the forest exploitation problem information and on the wine harvest production.
\end{abstract}

\section{Introduction}

\subsection{The state of the art}

Studies on historical climatology are available worldwide, and Bradley and Jones (1992), Pfister (1994), Pfister and Brázdil (1999), Bradley et al. (2003) and Brázdil et al. (2005), are of particular interest to Europe and the Mediterranean area. Spain has produced a solid body of work specializing in historical climatic reconstructions.

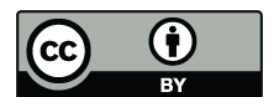

Correspondence to: T. Bullón (teresa.bullon@uam.es)
Several documentary sources found in Spanish archives can be used for climatic historical reconstructions. Religious and municipal documentary sources are often consulted for these purposes. The specific documentary organization of the most important Spanish archives, and the structure and typology of documents found in each is described by García Herrera et al. (2003).

Several areas of the Iberian Peninsula have been subjects of climatic reconstructions including Catalonia, (Martin Vide-Barriendos, 1995 and Barriendos, 1997) and Aragon (Vicente-Serrano and Cuadrat, 2007) northeast, Andalusia (Rodrigo et al. 1999, 2000, 2001) south, and Portugal (Alcoforado et al., 2000 and Taborda et al., 2004) southwest. This paper examines Castile, a region in central Spain, which is seldom researched although Rodrigo et al. (1998) and Dominguez- Castro et al. (2008) have published studies on this area. In addition, Rodrigo and Barriendos (2008) made a valuable contribution to the literature by coordinating all the data published for the entire Iberian Peninsula.

Precipitation prevails over thermal regimes as the dominant topic in most of the published works, because many authors believe that it adequately explains two important characteristics of Spain's climate: catastrophic floods (Barriendos and Martin Vide, 1998) and severe droughts. Many of the precipitation reconstructions are based on data contained in rogation ceremony books, because correlations can be drawn between the different levels of liturgical ceremonies and the intensity of the droughts (Martin Vide and Barriendos, 1995). More recent works such as Rodrigo and Barriendos (2008), Vicente-Serrano and Cuadrat (2007), Dominguez Castro et al. (2008) and Rodrigo (2008) improve the methodology, temporal definitions and global interpretation. The tendency to avoid thermal characteristics in reconstructions is directly linked to the scarcity of information. Thus far, no significant documentary sources have been found to chart the evolution of temperatures over time. 


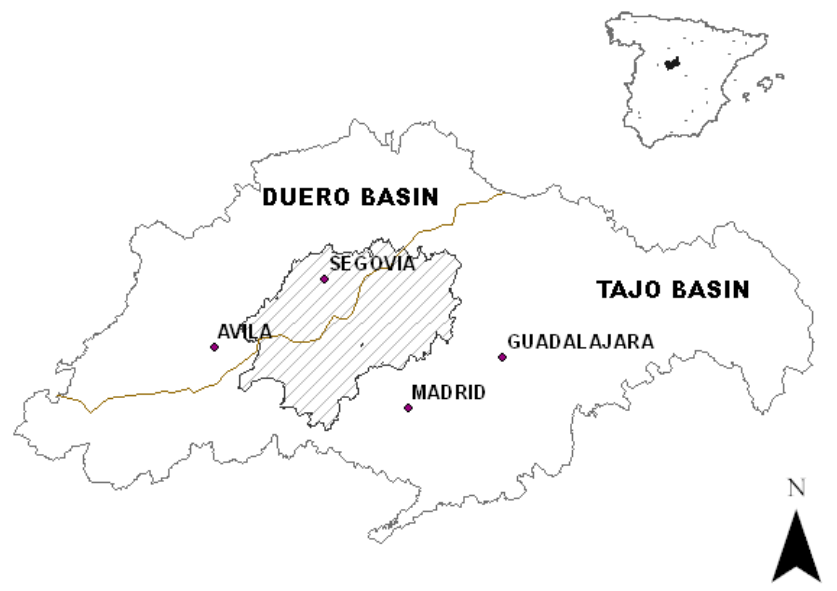

Fig. 1. Geographical location of the study area.

Analyses of special climatic periods are treated in the same way. Saz and Creus (2004) used dendroclimatology for studies on the Little Ice Age (LIA) and found that an increase in precipitation was the most important climatic effect for this period in Spain, with rainfall reaching a maximum during the latter half of the sixteenth century. Rodrigo et al. (1995) divided the LIA into tree periods: $1500-1550$ with dry conditions, 1550-1650, wet conditions, and, finally, 1650-1700, a return to dry conditions. The Maunder Minimum defined by Alcoforado et al. (2000) for Portugal, coincides with a period of unusual rains, sometimes heavy, mixed with cold spells of little significance. Barriendos and Rodrigo (2008) explain specific winter conditions from the sixteenth to twentieth century in relation to precipitation and floods and report an increase of rain in Andalusia and flooding of the Castilian Tagus (Tajo) river during the latter half of the sixteenth and early seventeenth centuries.

This paper examines a geographical area and a historical period of great importance for Spain, and some of the documentary sources consulted have also been used for significant works in historical research. Consequently, utmost care was taken in transcribing and interpreting the documentary data from the conclusions of such relevant and highly respected published historical works. The work of Garcia-Sanz (1975) was essential to developing the methodology used to interpret documental data, while Anes (1994), Garcia-Sanz $(1986,1994)$ and Kamen (1997) helped to place the data in its economic, political and social context. Also, the work of Colmenares (1970), and Sigüenza (1998) on contemporary memoirs related to this paper's topic were extremely useful. Research on forest history was aided by major studies by Gómez Mendoza (1992, 1996), and provide a clear characterization of the historical evolution of the forests.

\subsection{Location and geographical interpretation}

All of the documents used for information purposes are located within a $6000 \mathrm{~km}^{2}$ area in the Guadarrama Mountain Range of the Central Iberian System in central Spain (Fig. 1). The range is comprised of a set of aligned NE-SW ridges and valleys with piedmonts angled gently to the NW and SE. At the end of the sixteenth century, this area was covered by pine and oak forests of Pinus sylvestris, Quercus pyreanica, and Quecus ilex and inhabited by large stocks of game and fish. It also contained a stable population, concentrated in villages, cities and monasteries. There were several royal residences as well, since it was a favorite recreational area of Spanish monarchs. Anes (1994) and documents such as land surveys, registries, purchase agreements and damage claims to cultivated land attest to the fact that there were no significant changes in land use. All farming, forestry and livestock activities were strictly regulated.

Intense human activity evolved in the lower part of this region, below the slopes and summits of the mountainous area that reaches altitudes of $2430 \mathrm{~m}$., and is characteristic of Mediterranean high mountain ranges. During the Pleistocene, many glacial cirques, periglacial forms, and an array of associated glacial and periglacial sediments were formed. Periglacial and snow activity continued into the Holocene. Today, seasonal ground frost and snow patches signal the residual effects of these two periods of cold environment (Bullón, 1995).

The Guadarrama Range is a major watershed for the central Iberian plateau. Large rivers originate there and flow north to the Duero basin and south to the Tajo basin. Large debris flows are the result of the dynamics in the catchment areas, where sediments cover the lower part of the slopes in the form of alluvial fans. Presently, dense vegetation cover protects the thick and scarcely compacted Quaternary sediments from erosion, but if this vegetation were to be degraded by natural or human actions, severe erosive would take place.

\subsection{Objectives and contextualization}

The purpose of this research is to contribute to the body of knowledge on climate in the second half of the sixteenth century (1550-1599) through a close reading and interpretation of original handwritten documents from various archives.

The main objectives that underlie this research are to determine the temperature evolution during the second half of the sixteenth century, and the interaction of natural resources, land use, evolution of natural vegetation and climate. Other aims are to define the general winter temperature characteristics of the study area from 1550-1599, and to analyze the influence of climatic conditions on forest management evolution and wine production.

Unlike the major part of the body of research specialized in climatic reconstruction in Spain, this paper poses a time 


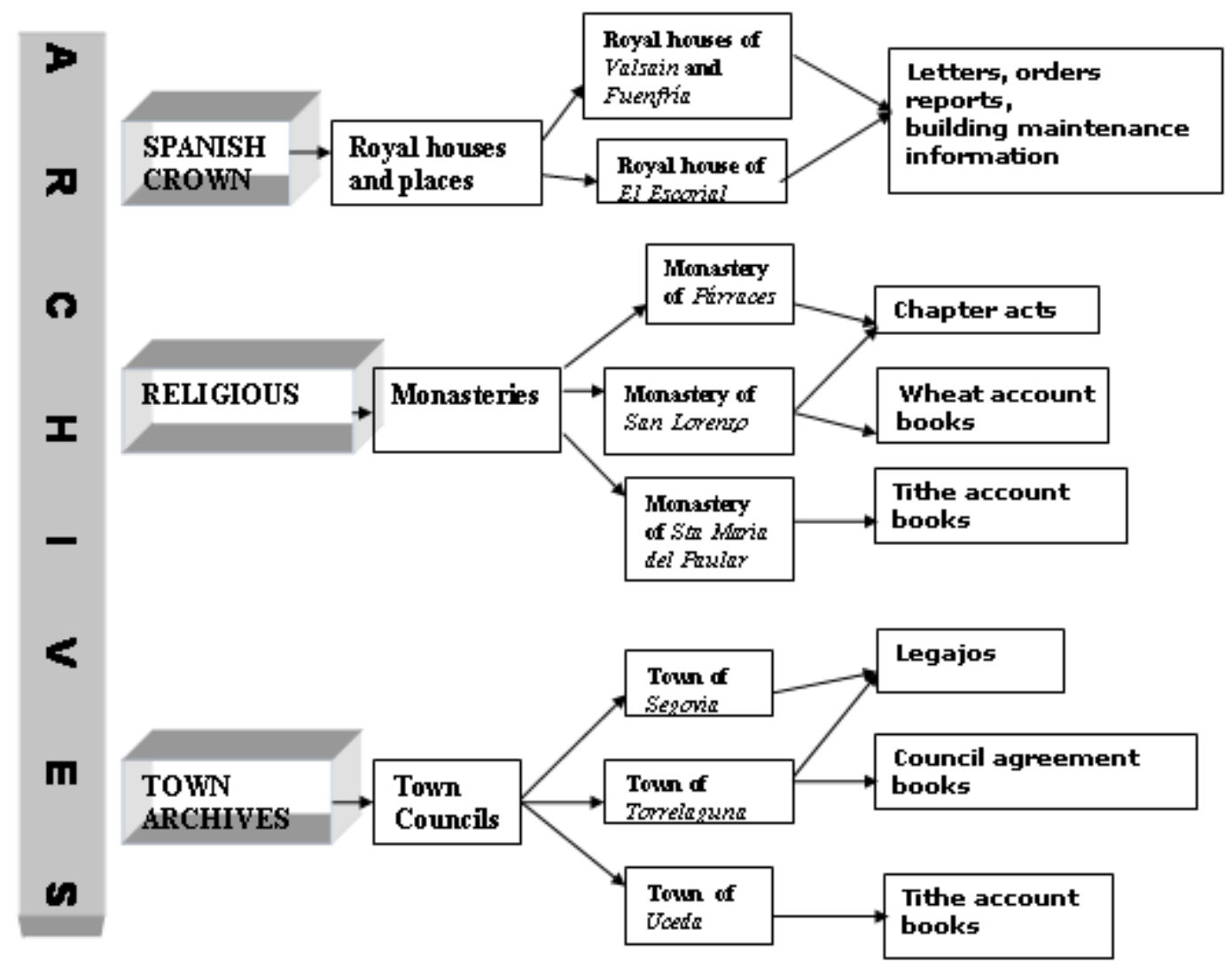

Fig. 2. Archives and collections consulted. The place names of monasteries and towns are in italics.

limitation, focusing on a 50 year period and on temperature instead of precipitation. This facilitates relating climatic results to a selection of natural resources and agricultural information. From this viewpoint, the study links directly to historical climate reconstruction analysis and to paleoenvironmental reconstruction sensu lato.

\section{Methodology}

\subsection{Gathering information and data collection}

All significant data on weather, climate or environment, pertinent to the study area, was collected from original coetaneous sources. No secondary sources were considered, with the exception of some previously published transcriptions (Modino de Lucas, 1995).

The archives and collections consulted belong to the Spanish monarchy, religious institutions and town councils (Fig. 2). Several manuscripts from the Spanish National Library were also consulted. Each of these documentary sources contains a certain kind of data with a specific meaning. Places associated with events are located in the study area at equidistant points, and as a whole, represent the most significant local landscapes and land uses. Figure 3 specifies the locations of these sites: northern piedmont (B) and southern piedmont $(\mathrm{I}, \mathrm{F}, \mathrm{G}, \mathrm{H})$ of the mountainous area; center $(\mathrm{C}, \mathrm{D}, \mathrm{E})$ and the extremes adjacent to the sedimentary basins that border the mountain $(\mathrm{A}, \mathrm{G}, \mathrm{H})$. This spatial localization guarantees accurate knowledge of the meteorological events that took place in the area and provides a means of cross referencing information.

The selected data was found in: (1) public documents such as monastery records, books of agreements, orders or royal dispositions that include references to natural events when they result in damage to goods or persons. Abundant information about the management of forest resources was found in these books from the Segovia Town Council. It should also be noted that these documents contain very interesting insights into forest analysis; (2) private correspondence, where spontaneous observations about events, especially weather, are common; (3) reports on the state of the royal forests and game, which were essential to justifying the problems that occurred and the actions proposed; and (4) tithe account books from a town located in the warmest southeastern part of the study site. Despite the variety of agricultural crops in the area, the study used only the data for wine production, expressed in a monetary unit called "maravedî".

The most explicit and valuable meteorological information is found in documents from the royal houses and palaces that form part of the collection of the Simancas General Archive. 


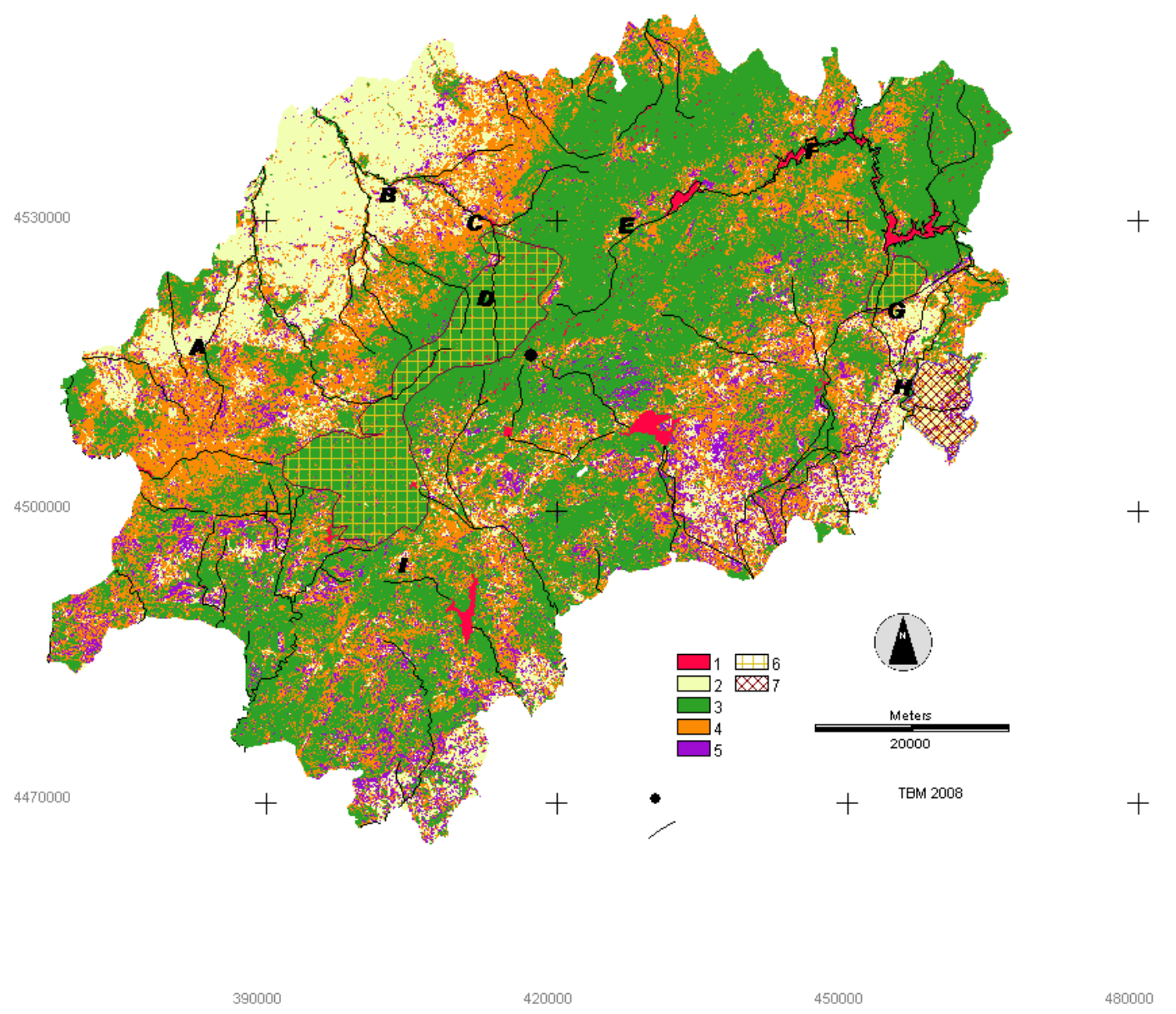

Fig. 3. Contemporaneous land use map of the study area from the Landsat 5 02/08/07 imagery. Captions: 1 Bodies of water. 2 Cultivated lands. 3 Pine and oak forest. 4 Shrubs and pastures. 5 Rocky, eroded and urban areas. 6 Wooded area most frequently reported in documents. 7 Vineyards and wine production areas. • Reference National Meteorological Station no. 62. A=Párraces. B=Segovia. C=Valsain. $\mathrm{D}=$ Fuenfría. E=Santa María del Paular. F=Biutrago. I=El Escorial. G=Torrelaguna. H=Uceda

Sometimes it is possible to find remarks on conditions for an entire winter such as: "There is no memory of such a terrible winter of snow and ice, with the ground completely covered for so many days" (dated 1571); or on extreme events: "At Reventón pass there was such a great storm (of snow and ice) that ten people died and six survived, and it is said that the six survivors lost their feet"( 1561); or inform about damages to royal houses: "The garden is exhausted and spoiled as a result of more ice than any other year" (1573), Legajos: 267/52 and 54, 267-1/79 and 267-1/140 of the cited collection and archive.

Municipal acts give more mundane information such as: "Due to the great amount of snow that has fallen in Valsain, the woodcutters cannot work and they have been idling since Monday" (1559), Segovia Council Agreement Book 10021007. Climatic references are less abundant in municipal acts, but they do provide more information about the ordinary life of the inhabitants. The Segovia Council agreement books also contain extensive information on forest management and have been used to assess the evolution of this natural resource. These annotations are different from those that have a climatic meaning and most are dated in the spring, summer or fall months. Tithe account books yield no additional information other than the systematic yearly reporting of agricultural and livestock production.

The average number of documentary records is 20.5 per year and $20 \%$ have fewer than 10 records. Likewise, there are at least 4 documentary records per year and $30 \%$ of them contain information about snow or ice. The accuracy of the information was verified by its overall temporal and spatial coherence and the concurrence of facts reported for a particular date from different places by individuals with no social contact and dissimilar interests. It is assumed, therefore, that the weather conditions described in the documents occurred as reported. When these occurrences justified damage to buildings, installations, or wooded lands, the recipients of the news believed in the veracity of the information, although they did not always accept it as an excuse. The time scales 
associated with these reports vary considerably. Some refer to events that span long periods of time such as whole seasons, while others refer to short-term phenomena lasting a day or even hours.

The collected data can be classified as follows: 1. direct data, which gives explicit information about meteorological events; 2. mixed data, associated with the direct data, and explains the consequences of the meteorological events and facilitates the evaluation of their intensity; 3 . indirect data, which describes the consequences of meteorological phenomena but not the meteorological events that caused them.

The direct and mixed data dated in December of the preceding year, January and February, while the indirect data had the following restrictions: (1) the relationship between the indirect and direct data was explicitly expressed in a database entry; (2) direct data was associated with indirect data when it was recorded during the same winter, although it may not have come from the same source. For most years there is direct and indirect data. The years with the most indirect data were also the years with the most direct data $(30 \%$ direct, $49 \%$ indirect and $21 \%$ mixed).

Most of the references on snow activity are found in reports by the land agents of the "Casa del Bosque" in Valsain, or wardens of the royal forests. Conditions at high altitudes were reported in sources that registered the amount and condition of the snow that would be used for human consumption by the monarch and his court and in narratives of travelers transiting high mountain passes. Snowfall data is scarcer for the northern sector of the mountains (northern piedmont) and is reflected only in council books of agreement, but the extent of the damages reported in these sources suggests heavy and widespread snowfall. Sources from the southern sector of the area (southern piedmont) include council books of agreement and records associated with the construction of El Escorial that relate to local weather conditions. The priors of the monastery, builders, royal secretaries and the king himself produced an abundance of correspondence, reports and orders containing varied and interesting information. The letters, in particular, reflect an extraordinary mastery in describing weather conditions. The interest and frequency of these missives were determined by the personality and background of the authors who were sparked by the king's insistent summons for information on any environmental change occurring in the vicinity of the monastery.

There are fewer and less frequent reports on ice conditions, so it is difficult to assess their impact. Also, the words ice, frost and cold are used interchangeably, so it is not always clear if the narrative refers to a specific or generic condition. The documents consulted describe episodes of freezing weather producing severe snow storms followed by more freezing weather, associated with stable weather and very low nocturnal temperatures, or very cold weather and strong winds. The records from the royal houses contain most of this information, because these entities kept close watch on the progress of the construction or rebuilding of the
Table 1. Table used to translate qualitative snow and ice events to quantitative information.

\begin{tabular}{lllr}
\hline Factor & & Concept & Score \\
\hline Loquacity & & High expressive source & -1 \\
& & Low expressive source & -2 \\
Geographic location & & Snow or ice at inner mountain & -1 \\
& & Sow or ice at base of mountain & -2 \\
& & Snow or ice at north piedmont & -3 \\
& & Snow or ice at south piedmont & -4 \\
Direct data & Definition & Big snow or ice storm & -1 \\
& of event & Very big snow or ice storm & -2 \\
& & Severe snow or ice storm & -3 \\
Mixed and & Damages & Building damage & -1 \\
indirect & produced by & Forest and trees Damage & -2 \\
data & snow or ice & Wildlife casualties & -3 \\
& & Human casualties from & -4 \\
& & hypothermia, inside buildings & \\
\hline
\end{tabular}

El Escorial monastery and royal houses and were concerned about the effects of cold weather on the building materials, completed constructions, gardens and water conveyances. The entries in council and monastery agreements books indicating such as orders for more coal to heat the municipal meetings halls, an increase in requests for permits to make coal in the municipal forests and regulations governing the use of fireplace fires in the monasteries, allow us to gauge the severity of the cold weather.

Most of the data relating to moderate and mild weather is direct data from personal correspondence. Indirect data is found in up-date reports on the progress of the construction of buildings outside the monastery, and other narratives on pleasant hunting expeditions, the good condition of the forests and game in early spring, and the descriptions of forest maintenance in areas that would be normally be inaccessible in winter.

\subsection{Data conversion}

The collected data was given a value according to equivalence tables and weighted based on the following criteria (see Tables 1 and 2): (1) the impact of the source to balance any bias derived from the writing style used in the document; (2) geographical location of data that takes into account the notable differences in climate according to altitude and slope aspects; (3) magnitude of the meteorological event with consideration to the significance of what is described; and (4) weighting of the actual damage produced by a particular event.

The methodologies proposed by Pfister (1994), MartinVide and Barriendos (1995) and Barriendos (1997), were used to obtain the final conversion from qualitative to 
Table 2. Table used to translate qualitative mild events into quantitative information.

\begin{tabular}{|c|c|c|c|}
\hline \multicolumn{2}{|l|}{ Factor } & Concept & Score \\
\hline \multirow{2}{*}{\multicolumn{2}{|c|}{ Loquacity }} & High expressive source & 1 \\
\hline & & Low expressive source & 2 \\
\hline \multirow{3}{*}{\multicolumn{2}{|c|}{ Geographic location }} & Mild weather at south piedmont & 1 \\
\hline & & Mild weather at north piedmont & 2 \\
\hline & & Mild weather at base of mountain & 3 \\
\hline \multirow[t]{2}{*}{ Direct data } & Definition & Not cold weather & 1 \\
\hline & of event & Mild weather & 2 \\
\hline \multirow{3}{*}{$\begin{array}{l}\text { Mixed and } \\
\text { indirect } \\
\text { data }\end{array}$} & Consequences & Ability to work or remain outside & 1 \\
\hline & of weather & $\begin{array}{l}\text { Healthy appearance of forest and trees } \\
\text { during the winter/spring interphase }\end{array}$ & 2 \\
\hline & & $\begin{array}{l}\text { Healthy appearance of wildlife during } \\
\text { the winter/spring interphase }\end{array}$ & 3 \\
\hline
\end{tabular}

quantitative data, because they were the most appropriate for dealing with the peculiarities of the research data.

The initial step in the search for the study's documental evidence was to determine if seemingly banal annotations actually contained significant weather information and referred to a specific geographic place. This would ensure reliable information about key meteorological events affecting a particular locality at the time the documents were written. Although an isolated reference to weather has virtually no interpretive value, if it is added to many other references that can be ordered thematically and chronologically, then it is possible to obtain reliable meteorological evidence.

Consequently, it was not necessary to produce a separate reconstruction for each source location rather for each reported event with a specific date. Each occurrence was given a maximum score in relation to its degree of importance in the documents regardless of the location. Situations of a similar type but taking place on different dates during the same winter were also reconstructed this way. Finally, the total value was obtained from the sum of all of the scores related to the intensity of the weather, cold or mild, during a given winter. In the most complex cases, a single value was assigned for the overall winter, based on indirect data from several places and documental references.

Events described as having low or very low temperatures were matched to the winter in which they occurred. Next, the sum of all the events, by year, was calculated and computed as a negative number $(-X)$, which expresses the impact of the cold events during a specific winter. Secondly, mild or warm winter occurrences were scored with a positive number using the established equivalence tables $(X)$. The yearly total of both sets: $(-X)+(X)$ gives an overall classification for each winter called the Winter Cold Intensity (WCI). Positive results denoted winters with predominantly mild temperatures and negatives, predominantly cold temperatures. A higher absolute value meant greater cold or mildness for any given winter. The correlation between the WCI series and
Table 3. Transfer functions used for temperature reconstruction.

\begin{tabular}{llllll}
\hline$X$ & $Y$ & $R^{2}$ & $a \pm \Delta a$ & $b \pm \Delta b$ & $\alpha$ \\
\hline $\begin{array}{l}\text { Reference series } \\
\text { ordinal index }\end{array}$ & $\begin{array}{l}\text { Reference series } \\
\text { temperature }\end{array}$ & 0.961 & $-0.504 \pm 0.042$ & $0.626 \pm 0.24$ & 0.000 \\
\hline
\end{tabular}

the forest resources and wine production series was used to validate the conversion to qualitative values.

\subsection{Temperature reconstruction}

The WCI values for the interval 550-1590, were compared to current winter values by converting them to anomalies from a 1961-1990 reference series. The method, according to Brázdil et al. (2005), reconstructs historical series in absence of overlapping documental and instrumental data in any period. This method is pertinent to the present study, because no sources dated after the early seventeenth century were found and those that were did not pertain to the instrumental period. The methodology consists of finding the correlation between an instrumental series and the ordinal indices series obtained from the instrumental series, Pauling et al. (2006) and Rodrigo and Barriendos (2008).

The historical and instrumental series were integrated in the following stages: (1) indexation, to produce two ordinal index series that is assigned separately to the raw WCI quantitative data and to the reference 1961-1990 series; (2) calibration, to determine the linear regression function (transfer function) between the index and the real meteorological series; (3) verification of results, to intercompare periods except for the calibration period; (4) reconstruction, the transfer function is applied to obtain the equivalence between historical and contemporary series.

The first step in temperature reconstruction was to assign an ordinal index with a value from +4 to -4 to the winter cold intensity series and to the reference series. This range of categories reflects the degree of coldness implied by the WCI numbers and expresses the inner variability of the reference series. Ordinal indices were assigned by establishing a grading system based on the distance between the standard deviations and the normal value for each of the two normalized series. The reference series in this study refers to the mean winter monthly temperature from 1961 to 1990 (INM, 1996) based on data from the National Meteorological Station no. 62 , located at $1887 \mathrm{~m}, 40^{\circ} 47^{\prime} 35^{\prime \prime}$ latitude and $04^{\circ}$ $00^{\prime} 40^{\prime \prime}$ longitude, in the center of the study area (Fig. 3).

The ordinal index assigned to the WIC was converted into temperatures, according to the proposed methodology, where the relationship between the ordinal index $(I)$ and the temperature $(T)$ is represented by Eq. (1):

$I=f(T)$

where $I$ is the ordinal index and $T$ the reference series temperature. The regression coefficients ( $a$ and $b$ ) of Eq. (1) are 


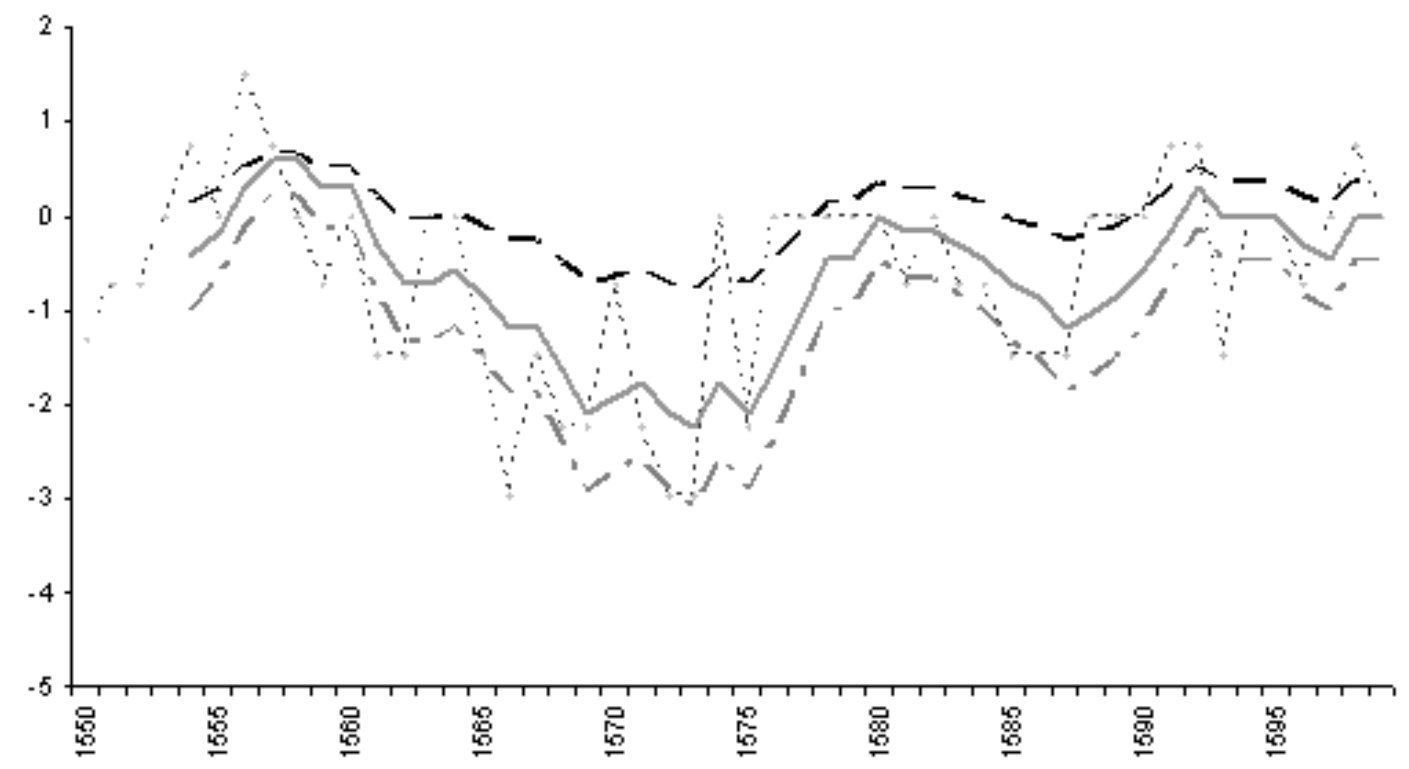

Fig. 4. Reconstruction of the 1550-1599 winter temperature anomalies. Dashed line: temperature anomalies reconstructed. Continuous line: 5 year moving average anomalies. Thick dashed lines: 5 year moving average of the error margins. 1961-1990 reference period.

applied to the ordinal index of the WCI to reconstruct temperature $\left(\operatorname{Tr}_{0}\right)$ :

$\operatorname{Tr}_{0}=a+I b$

An uncertainty factor was used to estimate the probable inaccuracies of the reconstruction, and to make allowances for margins of error $(\Delta a$ and $\Delta b)$ of Eq. 2. The transfer functions applied to the WIC index series to obtain the thermal uncertainty reconstruction $\left(\operatorname{Tr}_{1}\right)$ in ${ }^{\circ} \mathrm{C}$ (Table 3 ) are:

$\operatorname{Tr}_{1}=a \pm \Delta a+|I| b \pm \Delta b$

A similar reconstruction based on the data from the meteorological station and for a different time sequence (INM, 1984 series) was used to verify result accuracy.

The winter anomalies in the historical series are derived from the equation:

$X i-X$

where $X i$ is the reconstructed winter temperature and $X$ the reference series winter average (Jones and Hulme, 1996).

Qualitative criteria and statistics were used to analyze and interpret the anomalies series. Also a qualitative estimate of the quality of the adjustment for the instrumental and anomalies series was obtained from references to damages caused by winter storms and freezes, reported in the local press during the instrumental period (1961-1978).

\section{Main results and discussion}

The $R^{2}$ obtained for the series and associated indexes was $>0.9$. The linear regression between the real temperatures and the reconstructed ones are statistically robust $\left(R^{2}=0.927\right.$ $\alpha<0.001)$. These high variances prove that the range index selected for the reconstruction was appropriate and adequately expressed the main features of temperature variability (Table 3). The Kolmogorov-Smirnov test confirmed the normalcy of the anomalies series, $\alpha=0.02$. The $t$-test for differences between means (equal variances has been previously checked), $t=2.52 ; t_{95}=0.63 \pm 0.5$ eliminates the $H_{0}$ similarity hypothesis between the reference and the anomalies.

A scan of the local press for news about environmental damages caused by winter storms and freezes during reference series years 1961-1978, revealed a discrepancy between the accounts of local and historical sources on the seriousness of the damage, with the local press indicating only minor damage. The effects of the very cold winter of 1963 (Ordinal index $=-4$ ) were far more benign than those of 1572 and 1573 , that were marked by the massive loss of wildlife in the royal forests, and the loss of tree cover which is critical to ecological balance in the rural environment. Despite these differences, once the qualitative observations were made and the relative intensities between the historical and reference series were adjusted, the ordinal index appeared appropriate.

The 5-yr moving average curve of anomalies (Fig. 4), shows a sharp drop in temperatures between 1564 and 1575, and the series average of anomalies is $-0.6^{\circ} \mathrm{C}$ below the reference series $\left(-0.4^{\circ} \mathrm{C}\right)$.

The general thermal evolution deduced from the variability analysis can be summarized as follows:

1. Years 1550-1563: alternating severe and mild winters, with 1556 having the warmest winter of the series with $1.4^{\circ} \mathrm{C}$ higher than the reference series. 


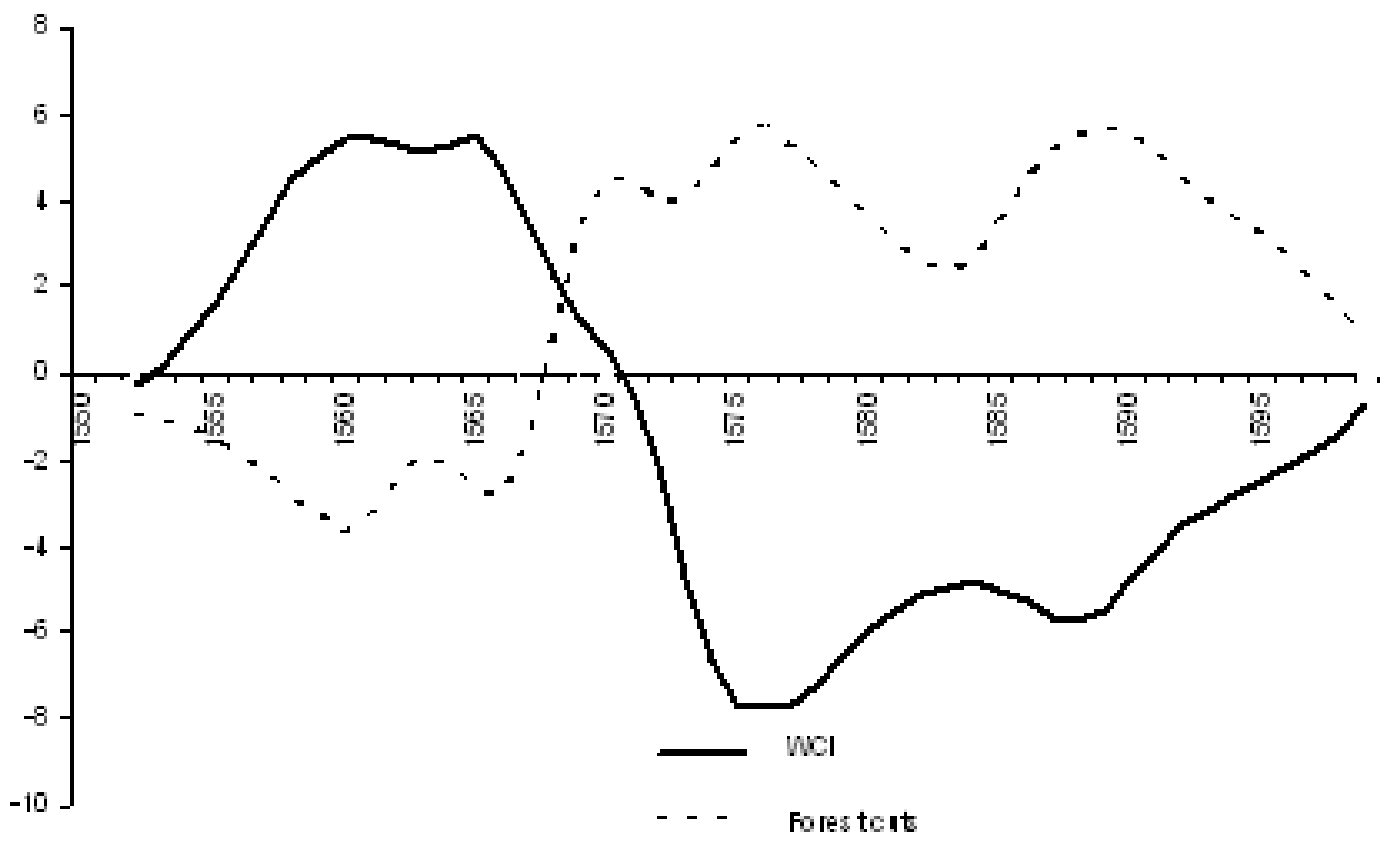

Fig. 5. Standardized WCI and controlled wood cuttings. 3 years moving average.

2. Years 1564-1575: the drop in temperature was more gradual, continuous and significant and reached minimums in 1572 and 1573 . The anomalies had average values of $-1.8^{\circ} \mathrm{C}$ and an uncertainty band from $-2.5^{\circ} \mathrm{C}$ to $-0.5^{\circ} \mathrm{C}$.

3. Years 1576-1582: evidence of a warming trend with temperatures reaching the reference average.

4. Years 1583-1587: another cold trend devolved and the average loss was $<-1^{\circ} \mathrm{C}$ (uncertainly band from $-1.8^{\circ} \mathrm{C}$ to $\left.-0.2^{\circ} \mathrm{C}\right)$.

The years from 1587 to the final year of the period was marked by a fluctuating recovery, up and down the average reference. Temperatures from 1564-1587 remained below the reference level with a global decrease of $-1.2^{\circ} \mathrm{C}$ (uncertainly band from $-1.8^{\circ} \mathrm{C}$ to $-0.2^{\circ} \mathrm{C}$ ).

These results concur with findings from authors such as Saz (2003, http://www.clim-past.net/4/357/2008/ cp-4-357-2008-supplement.pdf) for paleoclimactic reconstructions, based on dendrochronology, for the northern half of the Iberian Peninsula, and for the hydrographic area of the Duero basin where a significant part of the research site for this study is located. Conclusions by Saz and Creus (2004, http://www.clim-past.net/4/357/2008/ cp-4-357-2008-supplement.pdf) also coincide with the present findings in that a marked cooling trend affected the first and last quarter of the sixteenth century. Bradley and Jones (1992) and Bradley et al. (2003), also observed a striking drop in temperature in larger regions during the last third of the sixteenth century and associated it with the beginning of the Little Ice Age, and with one of the most severe climactic oscillations recorded during this period of climate change.

\subsection{Effects on the exploitation of natural resources}

\subsubsection{Forest resources}

A review of the number of permits granted to cut brush and trees provides proof that the intensity of forest resources exploitation was directly related to winter temperature conditions. The colder the winter, the greater the use of forest resources. Figure 5 shows a graphic comparison between the standardized accumulated WCI series and the annual number of permits granted to exploit forest resources. It also explains the inverse correlation of both curves. The correlation coefficient obtained for the two series is $-0.86,(\alpha=0.001)$. Interpretation of this finding should take into account that independent data was used to elaborate this two series (see Sect. 2.1).

Many documents refer to a significant decrease in existing forest mass during the period. Data associated with this deterioration point to excessive, and often illegal, logging and to widespread impoverishment of the timber mass. Deterioration in forest mass increased in the second half of the 1580s, after an accumulation of several years of cold temperatures.

The data reveals that vegetation also suffered. Some sources describe the vegetation on the edge of the timber line, which was lower then than it is today, and point out that the sclerophyll forests of Quercus ilex, located in the northern sector of the study area, were deteriorat- 


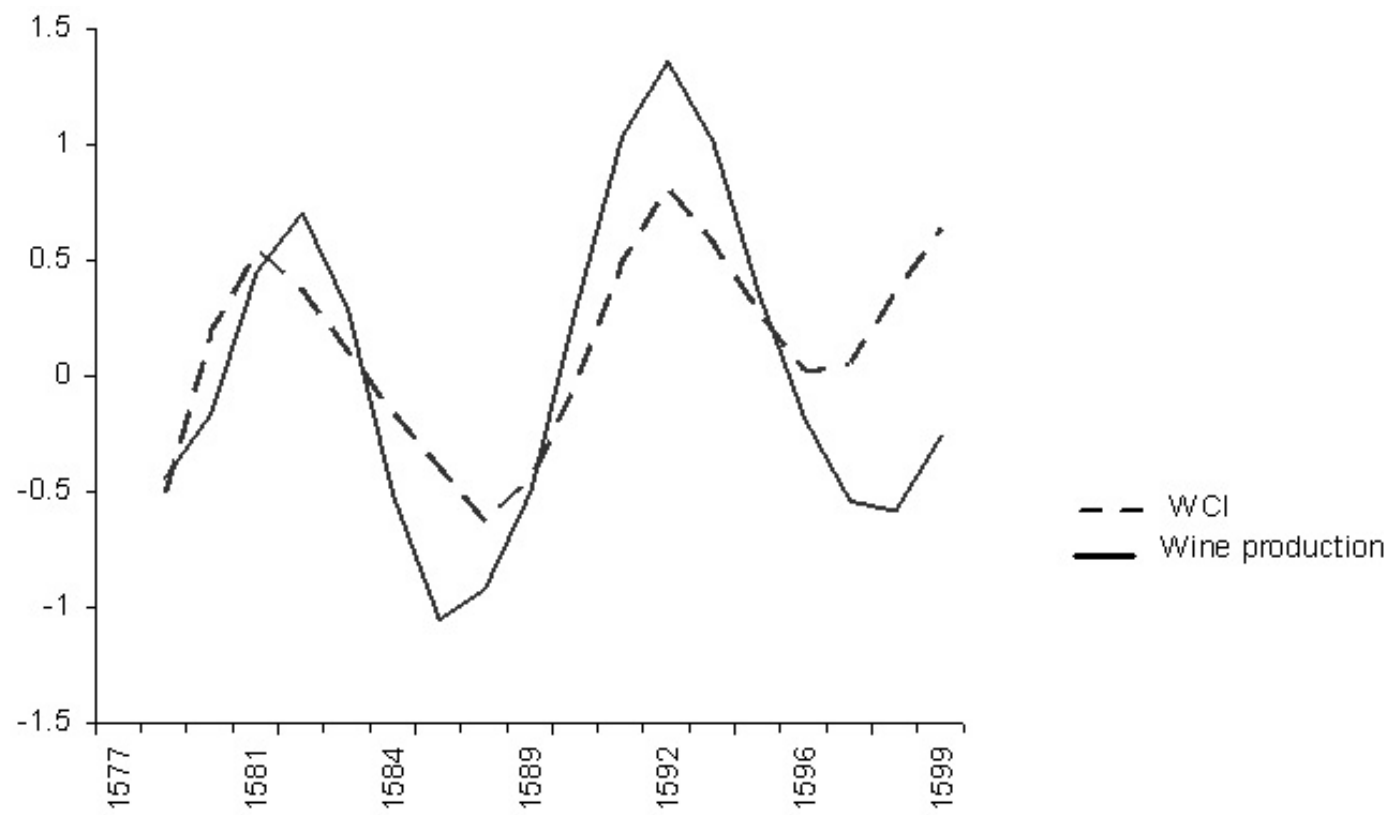

Fig. 6. Standardized WCI and wine production curves. 3 years moving average.

ing. After many severe winters, these forests now appear to be at the natural limit of their biogeographic habitat (Blanco et al., 1997, http://www.clim-past.net/4/357/2008/ cp-4-357-2008-supplement.pdf). The evidence presented in this study establishes that winter conditions were colder than they are today, so it would appear that natural causes were responsible for the deterioration of the vegetation. The vast deterioration of forest mass might also be attributed to periods of drought or specific forest mass destruction (e.g. fires or geomorphologic mass movements), but the evidence available points to the intensity of winter cold as the greatest cause of forest deterioration.

\subsubsection{Agricultural production}

Trends in annual agricultural or livestock production were verified by tithe payments in towns and villages within the study area. The town with the most reliable data is in the southeastern part of the site, where wine production seems to have been affected by changes in winter temperatures (Fig. 3, caption 7). Although the series for this activity spans only 22 years it generally coincides with the severest winters (minus the period $1564-1575$ which is missing), and the lowest wine production (Fig. 6).

Several research studies (Mullins, 1992; Lansteiner, 1999; Brazdil, 2005) show the effect of temperature on wine production, and most point out the close relationship between production and summer temperatures, but there is also a recognized secondary association that links severe winter frost to lower wine production. Under these conditions, exposed parts of the vine suffer damage in below-zero temperatures. The ability to withstand very cold temperatures varies according to the vine variety and the maturity of the wood (Winkler, 1974). Spanish phenological studies (http://www.clim-past.net/4/357/2008/ cp-4-357-2008-supplement.pdf) (León Llamazares, 1989 and Quiroga and Iglesias, 2005) also show that a significant decrease in production can occur after severe winters and if frost coincides with the moment the vines start to bud. The present study did not take into account spring and summer temperatures, for which more data and analysis are needed, and should form the basis for future research.

\section{Conclusions}

This paper shows the value of documentary resources that have never been used in climatic reconstructions in Spain. The data has significant and numerous references to meteorological events, which are sometimes quite explicit, and reveal the past climatic conditions were cooler than today's.

Information was gathered over a spatial network of documentary sources associated with a mountainous area. Interpretation was carried out by weighting data according to its specific climatic significance as well as other external factors such as geographical influence and the skill of the source's author in describing meteorological conditions.

In contrast to previous contributions to historic climatic reconstruction in Spain, which focused mainly on precipitation analysis, this paper limits its scope to temperature evolution during a phase of the Little Ice Age.

According to the available data from 1564 to 1575 , the temperature was $-1.8{ }^{\circ} \mathrm{C}$ with respect to the average of the reference series. This drop in temperatures was preceded by 
several years of relatively mild winters (1550-1563). A new marked drop occurred from 1583-1587, followed by a recovery, before reaching the reference average by the end of the study period. Temperatures from 1564-1587 remained below the reference level with an average global decrease of $-1.2{ }^{\circ} \mathrm{C}$. Contrasted data on the damages suffered during the reference and historical periods indicate that the severity of the periods of intense extreme cold was more pronounced in the second half of the sixteenth century than they are today.

Forest exploitation and wine production are sensitive to winter temperatures and their response to the drop in temperatures during the period 1550-1599 validates the effect of a colder temperature regime on the deterioration of the forest mass that is reflected in the documents consulted. Periods of draught may also be a cause and should be assessed in the future.

The exceptional climatic conditions existing during the study period explain the townspeople's urgency to obtain firewood. The drop in temperatures also may have affected the organization and structure of plant communities. Those now found at the limit of their spatial distribution determined by bioclimatic factors were the most affected by the colder temperatures.

In conclusion, this work demonstrates that a cold climate crisis existed, and its most significant phase coincided with a severe drop in temperatures that occurred from 1564-1587, and continued, with decreasing intensity, until the late sixteenth century. According to documents consulted, this crisis period corresponds to the Little Ice Age. Although this cold oscillation in Spain has not been totally defined chronologically in relation to temperature, the data presented in this article may help to identify its timeframe, the characteristics of the thermal decline and the related environmental consequences.

\section{Appendix A}

\section{Documentary sources}

Town Council of Segovia Archive. Agreement books: 1002-1007, 1007-1008, 1009-1011, and Legajos Collection.

General of Palace Archive. Fondo Patronato. San Lorenzo: Chapter acts from Monastery of Párraces: Legajos 1793-136, 1793-138.

General of Simancas Archive. Fondo Casas y Sitios Reales. Legajos: 267-I, 267-II, 259, 260, 261, 268, 280, 281, 291, 299, 302-3,302-4.

Historic National Archive: Fondo: Clero. Monastery of Santa Maria del Paular. Libros: 4286 and 19812.

Regional of Madrid Archive: Town Council of Torrelaguna Archive. Agreements books 14300, 14301, 14284.

Royal Monastery of San Lorenzo de El Escorial: Chapter acts book from XVI century.
Spanish National Library: Manuscripts 9937, 10857 , 11561, 11157, 1337.

Acknowledgements. The author would like to thank Professor Julio Muñoz of the Universidad Complutense de Madrid and the member of the Geoclimate Research Group of the Universidad Autónoma de Madrid for their help. Also the author wishes to thank two anonymous referees and editor of this paper for their useful comments.

Edited by: H. Dolman

\section{References}

Alcoforado, M. J., Nunes, M. F., Garcia, J. C., and Taborda, J. P.: Temperature and precipitation reconstruction in southern Portugal during the late Maunder Minumum (AD 1675-1715), Holocene, 10(3), 333-340, 2000.

Anes, G.: The agrarian "depression" in Castille in the seventeenth century, in: The Castilian crisis of the seventeenth century, edited by: Thomson, I., Cambridge University Press, Cambridge, 6077, 1994.

Barriendos, M.: Climatic variations in the Iberian peninsula during the late Maunder Minimum (AD 1675-1715): an analysis of data from rogation ceremonies, The Holocene, 7, 105-111, 1997.

Barriendos, M. and Martin Vide, J.: Secular climatic oscillations as indicated by catastrophic floods in the Spanish mediterranean coastal area (14th-19th centuries), Climatic Change, 38, 473491, 1998.

Blanco, E., Casado, M., Costa, M., Escribano, R., Garcia, M., Genova, M., Gómez, A., Moreno, C., Morla, C., Regato, P., Sainz, and H. : Los bosques ibéricos. Una interpretación geobotánica, Planeta Ed., Barcelona, 1997.

Bradley, R. and Jones P.: Climate since AD 1500, Routledge, London, 1992.

Bradley, R., Briffa, K., Cole, J., Huges, M., Osbon T: The climate of the last millenium, in: Paleoclimate, Global Change and the Future, edited by: Alverson, R., Bradley, R., and Pedersen, T., Springer, Berlin, 2003

Brázdil, R., Pfister, C., Wanner, H., Storch, H., and Luterbacher, J.: Historical Climatology in Europe - The State of the Art, Climatic Change, 70, 363-430, 2005.

Bullón Mata, T.: Hill slope erosion, environmental changes and land management on a Spanish mountain, Phys. Chem. Earth, 20(3-4), 339-344, 1995.

Colmenares, D.: Historia de la insigne ciudad de Segovia y compendio de las historias de Castilla, Academia de Historia y Arte de San Quince, Segovia, reprint (first edition 1637), 1970.

Dominguez-Castro, F., Santisteban, J. I., Barriendos, M., and Mediavilla, R.: Reconstruction of drought episodes for central Spain from rogation ceremonies recorded at the Toledo Cathedral from 1506 to 1900: a methodological approach, Global Planet. Change, 63(2-3), 230-242, doi:10.1016/j.gloplacha, 2008.

García Herrera, R., García, R. R., Prieto, M. R., et al.: The use of Spanish historical archives to reconstruct climate variability, B. Am. Meteorol. Soc., 84, 1025-1035, 2003.

García Sanz, A.: Los diezmos del obispado de Segovia del siglo XV al XIX. Problemas, métodos, modos de percepción y regímenes sucesivos de explotación, in: Actas de las I Jornadas 
de Metodología Aplicada de las Ciencias Históricas, Confederación Española de Cajas de Ahorros - Universidad de Santiago, Vigo, 143-152, 1975.

García Sanz, A: Desarrollo y crisis del antiguo régimen en Castilla la Vieja. Economía y sociedad en tierras de Segovia de 1500 a 1814, Akal ed, Madrid, 496 pp., 1986.

García Sanz, A.: Castille 1550-1650: Economic crisis and the policy of reform, in: The Castilian crisis of the seventeenth century, edited by: Thomson, I., Cambridge University Press, Cambridge, 13-29, 1994.

Gómez Mendoza, J.: Ciencia y política de los montes españoles. (1848-1936), ICONA ed., Madrid, 260 pp., 1992

Gómez Mendoza, J.: Geographical ideas among forestry naturalist in Spain, in: Geography and Professional Practice, edited by: Berdoulay, V. and Van Ginkel, J. A., Netherland Geographical Studies, 227-236, 1996.

Instituto Nacional de Meteorología (INM): Climatología de Puerto de Navacerrada, Madrid, 1984.

Instituto Nacional de Meteorología (INM): Valores normales y estadísticos de estaciones principales (1961-1990), Observatorio de Madrid Puerto de Navacerrada, Madrid, 1996.

Jones, P. and Hulme, M.: Calculating regional climatic time series for temperature and precipitation: methods and illustrations, Int. J. Climatol., 16, 361-377, 1996.

Kamen, H.: Philip of Spain, Yale University Press, New Haven, 1997.

Landsteiner, E.: The crisis of wine production in late sixteenthcentury Central Europe: Climatic causes and economic consequences, Climatic Change, 46, 323-334, 1999.

León Llamazares, A.: Caracterización agroclimática de la Provincia de Madrid, Ministerio de Agricultura, Pesca y Alimentación, Madrid, 1989.

Martin Vide, J. and Barriendos, M.: The use of rogation ceremony records in climatic reconstructions: a case study from Catalonia (Spain), Climatic Change, 30, 201-221, 1995.

Modino de Lucas, M.: Los priores de la construcción del Monasterio del Escorial, Vol.1 and 2, Patrimonio Nacional ed, Madrid, 1995.

Mullins, M. : Biology of the grapevine, Cambridge University Press, Cambridge, UK, 1992.

Pauling, A., Luterbacher, J., Casty, C., and Wanner, H.: Five hundred years of gridded high resolution precipitation reconstructions over Europe and the connection to large-scale circulation, Clim. Dynam., 26, 387-405, doi:10.1007/s00382-005-0090-8, 2006.

Pfister, Ch.: Climate in Europe during the late Maunder Minumum period (1675-1715), in: Mountain environments in Changing Climates, edited by: Beniston, M., London, 61-89, 1994.

Pfister, Ch. and Brádzil, R.: Climatic variability in sixteenthcentury. Europe and its social dimension. A synthesis, Climatic Change, 43, 5-53, 1999.

Pfister, Ch., Brázdil, R., Glaser, R., Barriendos, M., Camuffo, D., Deusth, M., Dovrovolny, P., Enzi, S., Guidoboni, E., Kotyza, O., Militzer, S., Rácz, L., and Rodrigo, F.: Documentary evidence in sixteenth-century Europe, Climatic Change, 43, 55-110, 1999.
Quiroga, S. and Iglesias, A.: Relación entre el clima y la productividad agraria: Diferencias regionales y entre cultivos, http://www. infoagro.com/hortalizas/relacion_clima_cultivo.htm, 2005.

Rodrigo, F., Esteban Parra, M. J., and Castro-Diez, Y.: The onset of the Little Ice Age in Andalusia (southern Spain): detection and characterization from documentary sources, Ann. Geophys., 13, 330-338, 1995, http://www.ann-geophys.net/13/330/1995/.

Rodrigo, F., Esteban Parra, M. J., and Castro-Diez, Y.: On the use of Jesuit Order private correspondence records in climate reconstructions: a case study from Castile (Spain) for 1634-1648 A.D., Climatic Change, 40, 625-645, 1998.

Rodrigo, F., Esteban-Parra, M. J., Pozo-Vazquez, D., et al: A 500year precipitation record in southern Spain, Int. J. Climatol., 20, 721-732, 1999.

Rodrigo, F., Esteban-Parra, M. J., Pozo-Vazquez, D., et al.: Rainfall variability in southern Spain on decadal to centennial time scales, Int. J. Climatol., 20, 721-732, 2000.

Rodrigo, F., Pozo-Vazquez, D., Esteban Parra, M. J. et al.: A reconstruction of the winter North Atlantic Oscillation index back to A. D. 1501 using documentary data in southern Spain, J. Geophys. Res., 106, 14 805-14 818, 2001.

Rodrigo, F. and Barriendos, M.: Reconstruction of seasonal and annual rainfall variability in the Iberian peninsula (16th-20th centuries) from documentary data, Global Planet. Change, 63(2-3), 243-257, doi:10.1016/j.gloplacha, 2008.

Rodrigo, F.: A new method to reconstruct low-frequency climatic variability from documentary sources: application to winter rainfall series in Andalusia (Southern Spain) from 1501 to 2000, Climatic Change, 87, 471-487, doi:10.1007/s10584-007-9312x, 2008.

Saz, M.: Temperaturas y precipitaciones en la mitad norte de España desde el siglo XV. Estudio dendroclimático, Publicaciones del Consejo de Protección de la Naturaleza de Aragón, Zaragoza, 2003.

Saz, M. and Creus,J.: Evolución de las temperaturas en Villacarriedo (Cantabria) durante la Pequeña Edad del Hielo, in: El clima entre el mar y la montña, edited by: García Codron, J. C., Diego, C., Fernández de Arroyábade, P., Garmendia, C., and Rasilla, D., Asociación española de Climatología y Universidad de Cantabria. Serie A, no. 4, Santander, 419-418, 2004.

Sigüenza, J.: La fundación del Monasterio del Escorial, Aguilar ed., reprint (first edition 1605) 1988.

Taborda, J. P., Alcoforado, M. J., and Garcia, J. C: The climate of southern of Portugal during the 18th century: a reconstruction based on descriptive and instrumental sources, Geoecologia, Rel. 2, Centro de Estudos Geograficos, Lisboa, 2004.

Vicente-Serrano, S. M. and Cuadrat, J. M.: North Atlantic oscillation control of droughts in north-east Spain: evaluation since 1600 A.D., Climatic Change, 85, 357-379, doi:10.10078s10584007-9285-9, 2007.

Winkler, A. : General viticulture, University of California Press, Berkeley, 1974. 